\title{
Studieavhopp inom 'Hum-Sam': Misslyckande eller strategi? Studenters egna berättelser om hur och varför de lämnade sina studier
}

\author{
Molly Sundberg och Paul Agnidakis \\ Uppsala universitet, Institutionen för kulturantropologi och etnologi
}

\begin{abstract}
Artikeln problematiserar studieavhopp utifrån studenternas egna upplevelser. Baserat på intervjuer med 24 studenter som hoppat av undervisning i etnologi och kulturantropologi vid Uppsala universitet urskiljer författarna två avhoppstyper: en mindre förekommande som är resultatet av ofrivilligt misslyckande, och en betydligt vanligare som sker frivilligt och efterföljs av studier i andra ämnen, ofta med tydligare yrkeskoppling. Artikeln lyfter fram bakomliggande orsaker i relation till detta avhoppsmönster. Dessa berör den enskilda institutionen, det statliga utbildningssystemet samt förhållanden inom humanistiska och samhällsvetenskapliga ämnen, såsom begränsade undervisningsresurser, hög andel fristående kurser och program utan yrkesexamen, och inte sällan låga antagningspoäng.
\end{abstract}

Nyckelord: Studieavhopp, genomströmning, studentperspektiv, etnografisk ansats, humanistiska och samhällsvetenskapliga ämnen, Uppsala universitet

Senare års politiska, tekniska och sociala förändringar i Sverige och internationellt har lett till en expansion och diversifiering av Sveriges studenter, med fler studieplatser och ökade möjligheter för studenterna att välja studiebana i termer av vad, hur, var och när de vill studera. Sedan slutet av I990-talet har antalet högskolestudenter ökat med närmare 30 \% (UKÄ, 20I3:26) och sedan 200I har universitet och högskolor i uppgift att bredda rekryteringen av studenter för att öka den sociala och etniska mångfalden (Högskolelagen, 200I). Sveriges deltagande i Bolognaprocessen, som syftar till att harmonisera EU-ländernas utbildningssystem och öka möjligheterna till internationell rörlighet, har medfört en ökad tillströmning av unga utländska EU-medborgare till svenska högskolor. Antalet utbildningar i Sverige har även vuxit, och med denna ökning så även bredden av ämnen att studera (Haikola, 20I5). Vidare har den digitala utvecklingen möjliggjort för många institutioner att erbjuda distansstudier via internet, vilket öppnat dörrar till högskolestudier för personer som tidigare stängts ute på grund av svårigheter att närvara $\mathrm{i}$ det fysiska klassrummet. Samtidigt tillhör Sverige ett av de länder inom $\mathrm{OECD}^{1}$ som har lägst genomströmning inom högre utbildning (OECD, 2013:64). Inte ens hälften av dem som börjar studera i Sverige avlägger en examen inom sju år (UKÄ, 2013:28). Prestationsnivån, mätt efter andel studenter som tar de högskolepoäng de har registrerat sig för, låg på $82 \%$ under läsåret 2013/I4. Vad beror detta på? En aspekt att beakta är ekonomiska strukturer och kvalitetsmått av högre utbildning. Institutionernas tilldelning av ekonomiska medel för undervisning vid svenska lärosäten baseras i större utsträckning på antalet registrerade studenter än antalet examinerade studenter. Studenter i Sverige kan beviljas studiemedel i flera år utan att uppnå godkänt betyg på en enda helterminskurs (CSN, 20I8). Även utbildningarnas omfattning, utformning och

*Författarkontakt: paul.agnidakis@etnologi.uu.se

Artiklar och reflektioner är kollegialt granskade. Övriga bidragstyper granskas av redaktionen. Se www.hogreutbildning.se ISSN 2000-7558

(C)2018 Molly Sundberg och Paul Agnidakis. This is an Open Access article distributed under the terms of the Creative Commons Attribution-NonCommercial 4.0 International License (https://creativecommons.org/licenses/by-nc/4.0/), allowing third parties to share their work (copy, distribute, transmit) and to adapt it, under the condition that the authors are given credit, that the work is not used for commercial purposes, and that in the event of reuse or distribution, the terms of this license are made clear.

Citation: Molly Sundberg och Paul Agnidakis (2018) «Studieavhopp inom 'Hum-Sam': Misslyckande eller strategi? Studenters egna berättelser om hur och varför de lämnade sina studier», Högre utbildning, 8(2), 116-130. http://dx.doi.org/10.23865/hu.v8.1273 
inriktning förtjänar uppmärksamhet. Statistik visar att genomströmningen är lägre på enskilda kurser $(70 \%)$ än på program ${ }^{2}(86 \%)$, liksom den är lägre på allmänna program (86 \%) än på yrkesinriktade program (90 \%) och lägre på nätbaserade kurser $(53 \%)$ än på campusbaserade (68 \%) (UKÄ, 20I7b:45). På senare år har även minskningen i prestation varit som störst inom ramen för enskilda kurser snarare än program. Internationellt pågår en diskussion om huruvida breddad rekrytering leder till sämre presterande studenter och lägre genomströmning. I Sverige visar studier inte på någon sådan koppling (UKÄ, 2017a). Däremot har ett samband påvisats mellan låg genomströmning och låga gymnasiebetyg och dåliga förkunskaper, som framförallt drabbar utbildningar med låga antagningspoäng (Högskoleverket, 2009; UKÄ, 20I7a). Vidare har antalet studenter med funktionsvariationer, såsom dyslexi och läs- och skrivsvårigheter, ökat och dessa studenter har ofta haft svårigheter på gymnasiet (Ingesson, 2007; Milrad, 20IO). Genomströmningsproblematiken är högst relevant för humanistiska och samhällsvetenskapliga utbildningar. Dessa erbjuder ett relativt stort antal fristående kurser, allmänna program som inte leder till en yrkesexamen, distansbaserad undervisning samt många utbildningar med låga antagningspoäng. ${ }^{3}$ Denna artikel undersöker genomströmningsproblematiken med fokus på avhopp från Institutionen för kulturantropologi och etnologi vid Uppsala universitet. Institutionen exemplifierar samhällsvetenskapliga och humanistiska utbildningar och problematiken som skildrats ovan. Sedan sammanslagningen av Uppsala universitet och Högskolan på Gotland i juli 2013 bedrivs en del av institutionens undervisning vid Campus Gotland, och då uteslutande över nätet och inom ramen för fristående kurser, medan övrig undervisning i etnologi och antropologi i Uppsala sker på campus. Den senare tar formen av både fristående kurser (om mellan 7.5 hp och $30 \mathrm{hp}$ ) och ett allmänt (utan yrkesexamen) kandidatprogram om I8o hp, 'Kultur, samhälle och etnografi' (KuSE), vilket kombinerar kurser i både antropologi och etnologi. Institutionen lämpar sig följaktligen väl som studieobjekt, eftersom den erbjuder kunskap om studieavhopp i relation till såväl olika undervisningsformer (nät- och campusbaserad) som olika utbildningsformat (enskilda kurser och allmänna program).

\section{SYFTE OCH FRÅGESTÄLLNING}

Denna artikel adresserar vad som ligger till grund för studieavhopp på basis av en empirisk undersökning av avhopp från studier på grundnivå vid Institutionen för kulturantropologi och etnologi vid Uppsala universitet. Syftet är att förbättra kunskapen om de komplexa orsakerna till studieavhopp inom framförallt humanistiska och samhällsvetenskapliga ämnen vid svenska lärosäten.

Artikeln tar sin utgångspunkt i avhoppade studenters egna berättelser om sina avhopp. Den undersöker den avhoppade studentens syn på avhoppet, på utbildningen som hen hoppat av samt på syftet med högskolestudier. Den undersöker även studentens relation till utbildningsansvariga samt hens individuella livssituation och studieförutsättningar. Studien analyserar den avhoppade studentens berättelser utifrån kunskap om den utbildning som hen har hoppat av samt de ekonomiska system och kvalitetsmått som strukturerar antagning och genomströmning inom högre utbildning och framförallt inom humanistiska och samhällsvetenskapliga ämnen.

\section{TIDIGARE FORSKNING}

De flesta undersökningar av avhopp från högre studier görs inom ramen för kvantitativa utredningar och utvärderingar, dels på nationell nivå (i Sverige av Universitetskanslersämbetet), dels vid specifika institutioner, fakulteter och lärosäten. Majoriteten är baserad på studentstatistik, enkätundersökningar (bland studenter) och, i mindre utsträckning, intervjuer (huvudsakligen med personal). Till de största interna projekten tillhör Trackit!, lanserat år 2010 av European 


\section{Molly Sundberg och Paul Agnidakis}

University Association (EUA) med syfte att kartlägga medlemsuniversitetens system för studentuppföljning. I Sverige medverkar Uppsala universitet, Malmö högskola, Högskolan Väst samt Lunds universitet (Smidt odaterad). Projektens utformning varierar mellan lärosätena men består i huvudsak av semistrukturerade fokusgruppsintervjuer med representanter från universitetsledningen, fakulteterna, den gemensamma förvaltningen, studentstödsverksamheter samt ett begränsat antal studenter. ${ }^{4}$ Därutöver har studieavhopp adresserats i undersökningar gjorda vid särskilda institutioner, bland annat vid Uppsala universitet (t.ex. Andersson et al., 20I2).

Många vetenskapliga studier har även utförts som berör (men inte nödvändigtvis begränsas till) högskoleavhopp, främst på universitet och högskolor i USA och Storbritannien, men även i till exempel låginkomstländer. Flertalet av dessa hämtar inspiration från Vincent Tintos (1987) teorier om vikten av social integrering i den akademiska miljön för studenters prestation. Många av studierna fokuserar på särskilda grupper studenter, med hänsyn till exempelvis kön och etniskt ursprung (t.ex. Borman, Halperin \& Tyson, 20ıо; Castellanos \& Jones, 2003; Flemming, 20I2; Huang et al., 2000), samt familjens tillgång till eller brist på akademisk utbildning (t.ex. Peelo \& Wareham, 2002; Quinn, 2005). En del forskning uppmärksammar särskilda program eller undervisningsformer (t.ex. Hede \& Wikander, I990; Svensson, 2004. Se även Andersson et al., 20I2; Borman et al., 20I0; Huang et al., 2000; Lutta, 20II; Simpson, 2003). En del av de mer kända avhoppsstudierna saknar helt de avhoppade studenternas egna röster, och baseras exempelvis uteslutande på statistik och utbildningsanordnares perspektiv (Peelo \& Wareham, 2002; McGivney, 2003). De studier som utgår ifrån avhoppade studenters perspektiv baseras på intervjuer (Hede \& Wikander, 1990; Castellanos \& Jones, 2003), enkäter (Flemming, 20I2; Huang et al., 2000) eller en kombination av båda (Borman et al., 20Io; Jönsson \& Johansson, 2007; Quinn, 2005; Simpson, 2003). Dock fokuserar den mesta av avhoppsforskningen på studenter som lämnat all slags högre utbildning (t.ex. Loresco, 20I3). Färre är de studier som behandlar de mer komplexa beteendemönster som urskiljs i dagens svenska (såväl som internationella) kontext, där avhopp från enskilda kurser eller program även kan handla om ett byte av studier, vilket innebär att studenterna stannar kvar inom högre utbildning (Allen et al., 20 I2. Se även: Barefoot, 2004; Hu \& Li, 20II; Scheg \& Shaw, 20I8). Vår studie ämnar bidra till den sistnämnda uppsättningen studier som undersöker avhopp från en kurs eller ett program, men med särskilt fokus på de avhoppade studenternas egna berättelser. Vi utvecklar detta forskningsområde genom att analysera det enskilda avhoppet i ljuset av studentens fulla studiebana, och genom att studera studentens egen upplevelse av avhoppet och dess orsaker och konsekvenser.

\section{EN ETNOGRAFISK ANSATS}

Vår studie undersöker problematiken kring studieavhopp utifrån en etnografisk ansats. Även om etnografin alltsedan 1970-talet är etablerad inom pedagogisk forskning, har dess användning som regel begränsats till vissa datainsamlingsmetoder, exempelvis intervjuer, som fătt utgöra ett alternativ till de traditionellt dominerande mer kvantitativa metoderna (Englund, 2004:38ff). Med inspiration från antropologiska och etnologiska ämnestraditioner har denna studie en etnografisk ansats i bredare bemärkelse och bygger på en kombination av perspektiv och metoder. Gemensamt för dessa är betoningen på individ- och mellanmänskliga nivåer (Agnidakis, 20I8). Vår etnografiska ansats har genomsyrats av ambitionen att studera studieavhopp som både individuella och kollektiva erfarenheter. Utgångspunkten har varit att förståelsen för varför vissa studenter 'presterar' medan andra inte gör det bör fokusera på studenternas egna upplevelser av sina studier och sitt avhopp, dess orsaker och förlopp. Samtidigt anser vi att dessa individuella upplevelser endast kan förstås i sitt större sociala sammanhang. Det 
senare kräver kunskap om exempelvis studentens fulla studiehistorik, den utbildning hen har hoppat av, de ekonomiska system och kvalitetsmått som strukturerar högre utbildning och de kulturella normer som influerar studentens syn på högre studier och dess genomförande. Vår studie närmar sig således studieavhopp som ett komplext socialt fenomen som fordrar en induktiv kunskapsansats och olika undersökningsmetoder. Den huvudsakliga metoden har bestått av resonerande etnografiska samtalsintervjuer med avhoppade studenter, vilket är en sedvanlig etnografisk metod inom antropologi och etnologi. Intervjuerna har utgått ifrån ett antal gemensamma teman, med mer eller mindre löst formulerade frågor. Syftet har varit att på ett förutsättningslöst vis ge studenterna möjlighet att kritiskt reflektera över processen kring avhoppet och hur det upplevdes, samt problematisera sitt eget förhållningssätt till avhoppet, dess orsaker och effekter (Frykman, 20I2:585f; jfr Craith et al., 2008; Ehn et al., 20I6). Med ambitionen att anpassa intervjuprocessen till studenternas skiftande förutsättningar och behov har vi som brukligt inom den här typen av etnografiska samtal varit flexibla i fråga om samtalsintervjuernas tidsramar. Deras omfång har varierat mellan drygt en till tre timmar. De ägde i regel rum på ett café eller en restaurang i informantens närhet, eller på institutionen där informanten för närvarande studerade (i Uppsala eller Stockholm). Intervjumaterialet har analyserats med hjälp av statistiska data från Uppsala universitet. Vi har samlat in och analyserat data avseende antalet studieregistreringar och examineringar på de kurser och program som inkluderats i studien samt de avhoppade studenternas fulla studiebana (hämtade ur UPDOK). ${ }^{5}$ Vi har även analyserat data över universitets övergripande ekonomi och studentgrupp, såsom antalet helårsstudenter respektive helårsprestationer vid UU:s olika fakulteter (hämtade ur GLIS ${ }^{6}$.

Som undervisande lärare och tidigare studenter vid den institution ifrån vilken de berörda studieavhoppen skett har vi även försökt dra nytta av våra personliga erfarenheter och kunskaper i tolkningen av våra studieresultat. Vi känner exempelvis väl till de olika kursernas ämnesinnehåll, och har med enkelhet kunna sätta oss in i kursernas upplägg under de terminer som våra informanter läst dem. Paul Agnidakis (etnolog) intervjuade studenter som hoppat av en kurs i etnologi, och Molly Sundberg (antropolog) intervjuade studenter som hoppat av en kurs i kulturantropologi. Båda intervjuade studenter som hoppat av programmet "Kultur, samhälle och etnografi." Samtidigt påkallar det faktum att vi båda är lärare vid den institution som våra informanter valt att lämna en etisk medvetenhet om vår eventuella inverkan på våra informanters vittnesmål. Det går inte att utesluta att vissa studenter tvekat att framföra kritik mot utbildningen på institutionen på grund av att forskaren som utförde intervjun arbetade som lärare vid denna institution. För att i möjligaste mån minska inflytandet av våra egna institutionskopplingar intervjuade vi inga studenter som deltagit $i$ en kurs eller ett program som vi som lärare undervisat på under samma termin. ${ }^{7}$ Vidare ägde få intervjuer rum på institutionen utan på mer "neutral" mark (se ovan). ${ }^{8}$

Under hösten 2016 utförde vi individuella intervjuer med 24 studenter som studerat vid Institutionen för kulturantropologi och etnologi, och som hoppat av en kurs på grundnivå någon gång under perioden vårterminen 20I3 - höstterminen 20I5, eller som hoppat av programmet Kultur, samhälle och etnografi under höstterminen 2009 - höstterminen 20I5. Av dessa var 9 f.d. studenter i kulturantropologi (A-, B- och C-nivå, samt de två fristående, engelskspråkiga kvällskurserna à I 5 hp, Culture in Armed Conflict och Afrikanistik), 5 f.d. studenter på KuSE-programmet och io f.d. studenter i etnologi (A-, B- och C-nivå, varav 2 på distans från campus Gotland). Vi har definierat en student som avhoppad om hen närvarat vid kursregistreringstillfället, men senare inte fullföljt sina studier. Vår studie inbegriper således inte studenter som anmält sig och antagits till en kurs eller ett program, men som inte dykt upp vid kursregistreringen. Studenterna 


\section{Molly Sundberg och Paul Agnidakis}

identifierades via UPDOK. Ursprungligen var planen att endast kontakta studenter som hoppat av studier under läsåret kalenderåret 20I3 och som inte fullbordat studierna vid intervjutillfället hösten 2016. Detta överensstämmer med måttet på prestationsgrad som Universitetskanslersämbetet använder sig av, där studier räknas som ofullbordade om studenten inte uppnått godkänt resultat senast tre terminer efter kursslut (UKÄ, 2017b:44). Men eftersom så få av de personer som hoppat av under kalenderåret 20I3 visade intresse av att delta i studien breddades urvalet till dem som hoppat av mellan vårterminen 2013 och höstterminen 20I5. Ingen av dessa avhoppade studenter hade slutfört sina studier vid början av vårterminen 2018 (vilket motsvarar mer än fyra terminer efter kursslut). Totalt kontaktades ca 170 studenter, vilket motsvarade nästan alla studenter som hoppat av en kurs eller ett program vid Institutionen för kulturantropologi och etnologi under vårterminen 2013 - höstterminen 2015 och till vilka det fanns aktuella kontaktuppgifter (se tabell nedan). Kontakt söktes via brev, epost, sms och telefon, beroende på vilka kontaktuppgifter som fanns tillgängliga i UPDOK, och beroende på vilken kanal som genererade respons. De flesta eller alla av de studenter på en kurs eller ett program som inte svarade på brev mejlades; de som inte svarade på epost, skickades sms; de studenter som inte svarade på sms, ringdes. Alla studenter som svarade att de ville delta i studien intervjuades. De som deltog gjorde detta utan kompensation och med full anonymitet. Något fler kvinnor (IS av 24) än män (9 av 24) deltog i studien, vilket mer eller mindre motsvarar könsfördelningen bland Uppsala universitets studenter som läser humanistiska och samhällsvetenskapliga ämnen (där 6 av Io är kvinnor, se Uppsala universitet, 20I7:68).

Tabell över studiens urval av informanter

\begin{tabular}{|c|c|c|c|c|c|}
\hline KURS/PROGRAM & TERMIN & $\begin{array}{l}\text { ANTAL } \\
\text { AVHOPPADE }\end{array}$ & $\begin{array}{l}\text { ANTAL REGI- } \\
\text { STRERADE PÅ } \\
\text { KURSEN }\end{array}$ & $\begin{array}{l}\text { ANDEL AVHOP- } \\
\text { PADE STUDEN- } \\
\text { TER }(\%)\end{array}$ & $\begin{array}{l}\text { ANTAL } \\
\text { INTERVJUADE }\end{array}$ \\
\hline KuSE-programmet & Hog-Vi6 & III & 226 & 49 & 5 \\
\hline Afrikanistik & $V_{13}$ & 9 & 39 & 23 & 2 \\
\hline Culture in Armed Conflict & $\mathrm{H}_{3} 3$ & II & 30 & 37 & I \\
\hline Antropologi A & $\mathrm{H}_{3} 3$ & 2 & 23 & 9 & I \\
\hline Antropologi A & His & 3 & I8 & 17 & I \\
\hline Antropologi B & $\mathrm{H}_{3} 3$ & 2 & $\mathrm{I} 3$ & 15 & I \\
\hline Antropologi B & $\mathrm{His}$ & 2 & II & I8 & I \\
\hline Antropologi C & $\mathrm{V}_{\mathrm{I} 3}$ & 3 & 23 & 13 & 2 \\
\hline Etnologi A & $\mathrm{H}_{3}$ & 3 & 20 & 15 & I \\
\hline Etnologi A & $V_{I 4}$ & $\mathrm{I} 3$ & 50 & 26 & 2 \\
\hline Etnologi B & $\mathrm{H}_{3} 3$ & 2 & 16 & $\mathrm{I} 3$ & 2 \\
\hline Etnologi B & VI4 Distans/CG & I & 8 & $\mathrm{I} 3$ & I \\
\hline Etnologi C & $\mathrm{H}_{3} 3$ Distans/CG & 7 & 15 & 46 & 2 \\
\hline Etnologi C & $\mathrm{H}_{3} 3$ & 3 & 9 & 34 & 2 \\
\hline TOTALT & & 172 & 501 & & 24 \\
\hline
\end{tabular}

Samtliga intervjuer fokuserade på ett gemensamt urval av teman som reflekterade studiens kunskapsmål. Samtidigt ville vi, i linje med studiens induktiva ansats, möjliggöra för våra informanter att lyfta andra teman utifrån deras egna perspektiv och erfarenheter. Detta bidrog till 
ytterligare nyansering och problematisering av studieavhopp som individuell och kollektiv erfarenhet. Huvudsakliga teman som berördes i intervjuerna var: Studentens förväntningar på och kunskap om de valda studierna; studentens upplevelse av utbildningen, lärarna och övriga studenter; studentens upplevelse av avhoppet (när under studieprocessen skedde avhoppet, vad föranledde det, på basis av vilken kunskap om regler/villkor/konsekvenser för avhopp, i samråd med vem?); studentens eventuella planer att återuppta sina studier; studentens postgymnasiala bakgrund och studievana vid avhoppet; studentens livssituation vid avhoppet (boende, ekonomi, civilstatus, sociala nätverk och/eller parallella studier/arbete); studentens identitet i termer av exempelvis genus, etnicitet, funktionsvariationer och socioekonomisk bakgrund (inklusive föräldrars/syskons akademiska och yrkesrelaterade bakgrund); studentens syn på högre utbildning, prestation och sin egen roll som student (varför läsa på högskolan, varför ämne och universitet?); studentens studiebana till dags dato, nuvarande livssituation samt tankar kring framtiden avseende studier och/eller arbete.

Intervjuerna registrerades via ljudinspelning och/eller med hjälp av skriftliga anteckningar (det senare i de fall ljudinspelning inte var möjligt ${ }^{9}$ eller inte medgavs av informanten). För att begränsa spridning av personuppgifter har inspelningar och anteckningar inte delats mellan oss två forskare. Insamling och analys av det empiriska materialet har dock präglats av kontinuerlig dialog, där observationer, tankar och slutsatser stötts och blötts gemensamt och lett till nya insikter kring både metod och analys.

Intervjumaterialet har transkriberats i den mån dess innehåll varit relevant för studiens teman och frågor. Delar av vittnesmål som inte bedömts relevanta har således inte transkriberats. En motsvarande avvägning har präglat själva materialframställningen. Individuella berättelser kring studieavhopp har lyfts fram utifrån hur de relaterar till de kollektiva berättelserna som vår analys utmejslat (se nedan). En sådan framställning går visserligen miste om förutsättningar att uppmärksamma en mångfald av röster, men vinner på möjligheterna att fånga de kollektiva och kontrastiva avhoppsprocesserna (se även Arvidsson, 1998:25f; Agnidakis, 2013:28).

\section{STUDIEAVHOPP: A WICKED PROBLEM}

Utöver våra informanters gemensamma intresse för studier i antropologi och etnologi vid Uppsala universitet utgjorde de intervjuade studenterna i många avseenden en heterogen grupp som i mångt och mycket representerar Sveriges studenter i stort. De hade sökt kursen eller programmet av en rad olika skäl - en del av en ren slump, några på grund av ett brinnande intresse för kultur- och samhällsprocesser, andra som komplement till studier i andra ämnen och ytterligare andra i jakt på ökad förståelse för sina sociala relationer i yrkes- eller privatlivet. Medan vissa personer var uppvuxna i akademiska miljöer och tog det som självklart att läsa vidare efter gymnasiet, var andra personer familjens eller vänskapskretsens enda "akademiker."

En femtedel av de intervjuade studenterna hade beslutat sig för att hoppa av redan under de första veckorna in i kursen, till exempel som följd av att de sökt och blivit antagna till fler än en kurs, läst båda kurserna parallellt i några veckor och sedan beslutat sig för att endast fullfölja den andra kursen. Något fler hade endast ett litet examinationsmoment kvar från att slutföra sina studier (till exempel en uppsatsventilering eller seminarieuppgift). Runt hälften av dem som läst kandidatprogrammet Kultur, samhälle och etnografi (KuSE) hade avbrutit sina studier genom att inte söka till nästa kurs i programmet. Vidare angav de flesta av våra informanter individuella skäl till sina studieavhopp, och dessa skäl skiljde sig avsevärt från varandra. I de flesta fall samverkade privata omständigheter (exempelvis sjukdom, dålig ekonomi, större intresse för andra studier, ändrade familjeförhållanden, parallella studier eller yrkesarbete) med 


\section{Molly Sundberg och Paul Agnidakis}

utbildningsspecifika upplevelser av kursen eller programmet vid institutionen. Studieavhoppen påvisade ingen tydlig koppling till informanternas genus, etnicitet eller sociala bakgrund (se UKÄ, 20I7a för liknande slutsats), och inte heller till undervisningens form (nät- eller klassrumsbaserad) ${ }^{10}$. Vi drar därför slutsatsen, i likhet med Colin Beer och Celeste Lawson (2017), att studieavhopp är ett wicked problem (Rittel \& Webber, 1973). Det vill säga orsakerna är många och ofta sammanvävda på komplexa och oförutsägbara sätt som gör dem svåra att effektivt motverka genom enskilda, avgränsade insatser. Vidare menar Beer och Lawson att dessa orsaker ofta verkar på olika nivåer - mikro, meso och makro. Våra informanter visade att orsaker på mesonivå (kopplade till utbildningen) samverkade med orsaker såsom parallella studier och ekonomi, vilka berör makro- såväl som individuella nivåer, eftersom de är kopplade till individens privata ekonomi liksom till statliga finansiella system.

\section{TVÅ SLAGS AVHOPPARE}

Utöver dessa mer övergripande observationer visar vår studie att avhopp från enskilda kurser eller program kan delas in i två grupper - en större (ca tre fjärdedelar) och en mindre (en fjärdedel).

\section{De ofrivilliga: avhopp som misslyckande}

Avhoppen hos en fjärdedel av informanterna var sällan ett aktivt val utan skedde mer eller mindre ofrivilligt - som en konsekvens av att studenterna inte klarade av kurskraven. Dessa personer hade vid intervjutillfället ofta andra oavslutade studier i bagaget. De flesta kämpade med särskilda utmaningar, i termer av psykologiska besvär, neuropsykiatriska tillstånd, ${ }^{\mathrm{II}}$ koncentrations- eller läs- och skrivsvårigheter, eller studieovana. I intervjuerna nämndes inte sällan att påbörjandet av (nya) studier på institutionen hade föregåtts av viss vånda men samtidigt en förhoppning om att man denna gång skulle klara av studierna. När studierna trots allt hade börjat gå dåligt hade dessa personer ofta dragit sig för att kontakta kursansvarig. Ingen hade heller haft kontakt med någon av universitetets studentstödsfunktioner, såsom universitets centrala och institutionsbaserade karriär- och studievägledare, studenthälsan (företagsvård för studenter), pedagogiskt stöd för studenter med långvarig funktionsnedsättning och språkverkstaden (som hjälper studenter med skriftlig och muntlig framställning). Efter att kursen tagit slut och studenterna stod utan betyg skämdes många för att kontakta kursansvarig trots att de fortfarande hade för avsikt att slutföra sina studier. Eftersom ingen på institutionen kontaktade dem heller, hade det hela så småningom runnit ut i sanden. Bristen på kontakt med kursansvariga och lärare framkom ofta i samtalen med dessa studenter. Den distans som progressivt utvecklade sig mellan studenterna och deras lärare (vilka ofta även var deras examinatorer) till följd av studenternas allt sämre självförtroende och skamkänslor över sin undermåliga studieprestation, främjades av institutionens allmänt begränsade uppföljning av studenternas insatser under och efter kursen.

Här kan Daniels studier i kulturantropologi tjäna som exempel. Daniel, en man i 20-årsåldern, påbörjade A-kursen i kulturantropologi om $30 \mathrm{hp}$ för drygt tre år sedan. Vid intervjutillfället hade han en rad oavslutade studier bakom sig, både vid Uppsala universitet och vid ett annat universitet som han läst vid på distans. Fastän han beskrev sig som ambitiös och intresserad av en rad olika ämnen, hade han alltid haft svårt att koncentrera sig. Daniel hade aldrig genomgått någon formell utredning men trodde att han led av ADD (Attention Deficit Disorder). Vidare hade han periodvis lidit av depressioner och saknat studiemotivation, bland annat till följd av personliga trauman, vilket har försvårat eller helt omöjliggjort universitetsstudier. När Daniel läste Kulturantropologi $\mathrm{A}$ fick han godkänt betyg på kursens första två delmoment men klarade 
inte det tredje delmomentets hemtentamen. Fastän han deltog i undervisningen på det ffärde delmomentet skrev han aldrig klart uppsatsen, vilket var delkursens huvudsakliga examinerande moment. Daniel insisterade att det aldrig varit hans avsikt att hoppa av. Han hade inte meddelat läraren när han insett att han inte skulle bli klar med uppsatsen på sista delmomentet, och ingen hade hört av sig till honom efter att deadline passerat. "Jag skäms för att inte ha lämnat in [examensuppgifterna]." Han hade många gånger tänkt att han skulle höra av sig till sina lärare och be att få fullfölja sina studier. "Men det är pinsamt att höra av sig långt senare. Det blir en massa jobb för läraren att rätta ersättningsuppgifter." Men han ville göra klart dessa kurser ”- för att ta revansch, för att bevisa att jag kan”. Daniel kände ett stort behov av upprättelse och erkännande. Han hade aldrig känt sig hemma i den akademiska världen, hans föräldrar hade aldrig läst på högskolan. Bland sina kurskamrater hade han känt sig "väldigt olik". Fastän han funnit de flesta kurskamraterna trevliga hade han inte haft något gemensamt med dem. Studierna hade heller inte erbjudit många tillfällen till social interaktion, vare sig innanför eller utanför klassrummet. Vid intervjutillfället hösten 20I6, när Daniel inte längre läste vid universitetet, hade han inga vänner kvar från studietiden.

Daniels berättelse belyser inte bara hur högskolestudier för vissa studenter innebär för stora studierelaterade utmaningar utan även hur sociala faktorer kan inverka negativt på studenter med särskilda utmaningar. Hos våra informanter med studieovana, psykologiska besvär och/ eller koncentrationssvårigheter inkluderade berättelser om studiemisslyckande ofta erfarenheter av brist på kamratstöd och på samhörighet och social interaktion med andra studenter i klassen. Detta handlade inte i första hand om ett ouppfyllt behov av konkret studiehjälp, utan snarare om hur dessa studenters känslor av underlägsenhet och utanförskap, till följd av dålig studieprestation, hade kunnat minskas om de getts större möjligheter att skapa förtroendefulla relationer med andra studenter i klassen. Medan Daniels föräldrar inte hade läst på högskolan, kom flera studenter i denna grupp från familjer med akademisk bakgrund. Känslan av utanförskap handlade således inte i första hand om klasstillhörighet utan om individuell studieprestation. Att olika uttryck för alienation kan utgöra en bidragande faktor till studieavhopp, inte minst bland berörda kategorier av studenter, har återkommande uppmärksammats av forskningen (jfr Castellanos \& Jones, 2003; Flemming, 20I2:34ff; Peelo \& Wareham, 2002:79ff; Tinto, I987:39, 53). Det bör samtidigt påpekas här att förutsättningarna för olika grader och former av undervisningsstyrd interaktion under en utbildning skiljer sig mycket från en institution och utbildning till en annan. Våra informanter talar utifrån sina erfarenheter av studier vid Institutionen för kulturantropologi och etnologi vid Uppsala universitet, och dessa erfarenheter är långt ifrån allmängiltiga för all slags pedagogisk verksamhet vid lärosäten. De är däremot inte ovanliga bland humanistiska och samhällsvetenskapliga ämnen, vars utbildningar erbjuder förhållandevis få klassrumstimmar och inkluderar ett stort mått av individuella självstudier (TCO, 20I3). Fastän ersättningsnivåerna för utbildning i humaniora, samhällsvetenskap, teologi och juridik har ökat på senare år, är de ekonomiska resurserna för undervisning fortsatt begränsade. De allra flesta av våra informanter med särskilda utmaningar hoppades, precis som Daniel, att en dag kunna slutföra sina studier. Faktum var att de var de enda avhoppare i studien som vid intervjutillfället hade för avsikt att fullborda sina studier vid institutionen. En del av dessa uttryckte en viss stolthet över att de gjort sitt bästa i sina studier och klarat sig så pass långt $\mathrm{i}$ utbildningen som de gjort. Trots detta framkallade avhoppet hos de flesta främst en känsla av misslyckande. Kopplat till detta fanns en oro över huruvida man överhuvudtaget skulle kunna återuppta studierna på institutionen eller i andra ämnen för att uppnå en högskoleexamen (jfr Peelo \& Wareham, 2002:74ff, 79ff; Quinn, 2005:38). Därtill medförde avhoppet inte sällan en 


\section{Molly Sundberg och Paul Agnidakis}

ekonomisk belastning i form av exempelvis förbrukade eller förlorade studielån, till följd av för många avhopp eller för att man inte kunnat tillgodoräkna sig avhopp från fristående kurser (jfr Tinto, 1987:79f; Jönsson \& Johansson, 2007:4I).

\section{De frivilliga: avhopp som strategiskt val}

Medan studieval och studieavhopp bland den första fjärdedelen studenter upplevdes som ett risktagande präglat av besvikelser, innebar avhoppen för de resterande, tre färdedelar av studenterna ett risktagande med positiva konnotationer. Avhoppen i dessa fall utgjorde ett slags språngbräda till andra studier - en möjlighet att orientera sig akademiskt för att hitta fram till "rätt" utbildning. De allra flesta av dessa studenter hade framgångsrikt gått vidare med andra högskolestudier sedan sitt avhopp. De få som inte studerat vidare hade återvänt till yrken de arbetat inom före eller parallellt med sina studier. Dessa studenter såg med andra ord inte sina avhopp som något misslyckande eller något som inverkat negativt på deras akademiska eller yrkesmässiga bana och motsvarande har för övrigt uppmärksammats i andra studier kring studieavhopp (Jönsson \& Johansson, 2007:20; Quinn, 2005:37ff; Tinto, 1987:Iff, I32). Studenterna i denna grupp hade ett anmärkningsvärt oreflekterat och oproblematiskt förhållningssätt till sitt studieavhopp och de saknade i regel avsikt att någonsin slutföra sina studier. Dessa studieavhopp har en del likheter med dem hos studenterna med särskilda utmaningar: Få förknippade sitt avhopp med en aktiv handling eller ett definitivt beslut, och få hade en tydlig bild av villkoren för studieavbrott. Med undantag för en person som besökt institutionens studievägledare inför sitt avhopp hade ingen heller haft kontakt med någon av universitetets studentsstödfunktioner. Vidare hade få meddelat sitt avhopp till institutionen, och i stort sett ingen hade kontaktats av institutionen med information om villkoren för studieavhopp, förfrågan om studentens skäl till avhoppet eller med uppmuntran att fullborda sina studier. Däremot uppgav flera studenter i denna grupp, framförallt programstudenter, att avhoppen hade gjorts i samråd med kurskamrater. Anledningen till att de exkluderat institutionen från sitt övervägande att lämna studierna var inte att de skämdes över att eventuellt inte fullborda sina studier (vilket var fallet med många studenter i den första gruppen). Snarare såg de beslutet som något som enbart berörde dem själva. Detta pekar på att dessa studenters studiebana och studietakt anses - av studenterna själva - som en högst privat angelägenhet och inte något som behöver diskuteras med institutionen.

Som exempel kan nämnas Karin, en kvinna i sena 2o-årsåldern som påbörjade institutionens kandidatprogram, KuSE, för drygt fyra år sedan, men hoppade av två år senare. Karin beskrev sitt val att läsa och sedan lämna programmet på följande sätt: "Jag har ju alltid varit intresserad av kultur och kulturhistoria och visste att jag ville jobba med detta på typ museum eller arkiv, och tyckte det var urkul att sånt här togs upp så mycket första året [...] Sen under år två blev det lite mindre av sånt här, även om vi hade lite kulturarvsteman och sånt som ändå gjorde det intressant för mig att läsa vidare och vilja slutföra programmet [...] Men efter att de första kurserna börjat och mest handlade en massa om nutida kulturer och postkolonial teori, började man ju fundera om det här [programmet] verkligen skulle ge mig det jag behövde för att gå vidare i livet med jobb, och då kände jag till slut att jag behövde se mig om efter något bättre [...] Vi var fler, minns jag, som tänkte så och kände oss väl lite besvikna på hela utbildningen.” Karins besvikelse ledde till att hon hoppade av KuSE-programmet. Efter fyra avslutade terminer lämnade Karin KuSE-programmet i samråd med andra kursstudenter, men utan att tala med någon personal vid institutionen. Karin och två studiekamrater använde senare de två års studiepoäng de erhållit från KuSE-programmet till en allmän kandidatexamen som gav behörighet att söka till en yrkesinriktad masterutbildning inom samma fakultet. Idag arbetar de tre 
studiekamraterna inom masterutbildningens yrkesområde och har enligt Karin inte ångrat sitt avhopp från KuSE-programmet.

Karins berättelse pekar på ett förhållningssätt till högre utbildning som ett smörgåsbord av utbildningsmöjligheter varifrån det går att välja och vraka, pröva och lämna. Det reflekterar en individualistisk och instrumentell syn på högre utbildning, där studieavhopp likställs med att "välja bort" en utbildningsmöjlighet till fördel för en annan. Den begränsade betydelse och privata natur som många studenter tillskriver sina avhopp bidrar möjligtvis till att förklara det ljumma intresset för deltagande i vår egen studie, som efter upprepade kontaktförsök endast lyckades engagera mindre än en sjättedel av tillfrågade studenter. Den vittnar om hur studieavhopp för många studenter är en relativt oproblematisk och högst privat företeelse - något som görs utan diskussion eller konsultation med utbildningsansvariga.

Karins berättelse belyser även klagomål som många av avhopparna i denna grupp riktade mot studierna de lämnat, nämligen bristen på tydlig information om utbildningens yrkesrelevans och konkreta ämnesinnehåll. Nästan hälften av studenterna som "valt bort" en kurs eller ett program angav att de haft svårt att förstå vad utbildningen handlat om och vad kunskapen den förmedlade hade för användning. Drygt hälften av de avhoppade studenterna hade upplevt tvivel kring utbildningens arbetsmarknadsmässiga konkurrenskraft. Andra hade hoppat av därför att de funnit utbildningen ointressant, eller på grund av privata omständigheter såsom bostadsflytt eller ändrade ekonomiska förhållanden. Värt att uppmärksamma är emellertid att i likhet med Karin, som hoppat av ett allmänt program till fördel för ett yrkesprogram, hade i stort sett alla informanter som efter avhoppet fortsatt med studier på annat håll gått vidare från en kurs till ett program, eller från KuSE-programmet till mer yrkesinriktade studier. ${ }^{12}$ Studieavhoppen motiverades alltså av studenternas uppskattning av utbildningens mindre ekonomiska eller arbetsmarknadsmässiga nytta relativt till andra möjliga utbildningar. Som fallet med Karin exemplifierar underlättas avhopp från program och längre kurser av att högskolepoäng som erhållits före avhoppet ofta kan användas i en annan examen. Att studenter utnyttjar möjligheten att tillgodoräkna sig poäng från avhoppade studier är för övrigt relativt vanligt i Sverige (UKÄ, 20I7b:46). I likhet med problematiken kring studieavhopp och begränsad lärarledd undervisning visar även analyser från både UKÄ och UHR att framförallt humanistiska och samhällsvetenskapliga ämnen är särskilt utsatta för studieavhopp till följd av utbildningarnas upplevda brist på yrkeskoppling. Anledningen är att dessa ämnen erbjuder en stor andel fristående kurser och liten andel yrkesprogram (UKÄ, 20I7b:90; UHR, 20I8).

\section{STUDIEAVHOPP: ETT KOMPLEXT PROBLEM SOM KRÄVER KOLLABORATIVA LÖSNINGAR?}

Studieavhoppen bland majoriteten informanter speglar studenters generella attityder till högre utbildning och uppmärksammar även frågor kring högskoleväsendets regelverk. Våra informanters ansats till högre studier exemplifierar till viss del den individcentrerade samhällsanda som präglar många västerländska samhällen, där den enskilda personen sätts i första rummet, och där universitetsstudier väljs och väljs bort efter individens behov, resurser och intresse. Liknande observationer har gjorts i USA. Högskolepedagogen Betsy Barefoot (2004) skriver att de flesta studieavhopp från amerikanska högskolor inte är resultatet av akademiskt misslyckande utan studenternas generella brist på "produkt-lojalitet" (product loyalty) och, som hon skriver, deras ständiga jakt efter grönare gräs inom utbildningsväsendet. I likhet med vår studie om avhopp från individuella kurser och program vid Uppsala universitet påvisar Barefoot att ett studieavhopp ofta handlar om att studenten söker sig till en annan utbildning eller högskola, snarare än 


\section{Molly Sundberg och Paul Agnidakis}

att hen helt lämnar högre studier. I USA innebär högre utbildning ofta höga kostnader för den enskilda studenten och antalet utbildningsgivare är mycket stort (ca 4000, Barefoot, 2004:I2). Detta påverkar studenters benägenhet att "utöva sin rätt" (Barefoot, 2004:I2) att lämna en utbildning om de inte är nöjda med den. I Sverige är högre utbildning avgiftsfri för svenska (och EU-) medborgare, och antalet utbildningsgivare är mycket färre (47). ${ }^{13}$ Samtidigt speglar våra avhoppade studenter en liknande självuppfattning som berättigade till högre studier och till möjligheten att pröva och lämna utbildningar därinom. I USA bottnar detta berättigande i en nyliberal konstruktion av studenter som konsumenter av utbildning, vilken framförallt bedöms på basis av dess konkurrenskraft på arbetsmarknaden (Saunders, 20IO). Våra informanter indikerade ett liknande synsätt $\mathrm{i}$ och med att många motiverade sitt avhopp med utbildningens avsaknad av yrkesrelevans, och $\mathrm{i}$ och med att de flesta senare hade gått vidare till mer yrkesinriktade studier. Genomströmningsproblematiken vid svenska lärosäten är således högst relevant för humanistisk och samhällsvetenskaplig utbildning, vilken erbjuder ett relativt stort antal fristående kurser och allmänna program som inte leder till en yrkesexamen. Samtidigt grundas troligtvis våra informanters känsla av berättigande till högre utbildning även i svenska studenters identitet som medborgare (snarare än konsument, som i USA). Våra informanters förhållningssätt till studieavhopp bör ses i ljuset av det skattefinansierade välfärdssamhälle i vilket de flesta av Sveriges studenter växer upp, där högre utbildning, i likhet med grundutbildning, sjukvård och barn- och äldreomsorg, ses som en medborgerlig rättighet (se även Allen et al., 20I2). Studenter tilldelas statliga ekonomiska medel för att läsa vid högskolan. Centrala Studiestödsnämnden (CSN) kan bevilja en högskolestudent studiemedel i flera år utan att studenten uppnått godkänt betyg på en enda helterminskurs. Kravet från CSN är att studenten klarar minst 45 av 60 hp per läsår (CSN, 20I8). Det räcker således att ta $22.5 \mathrm{hp}$ per termin, motsvarande 3 av 4 delmoment av en $30 \mathrm{hp}$-kurs, trots att detta inte ger något betyg på den enskilda kursen.

Svenska lärosäten rankas, jämförs och konkurrerar om statliga och privata medel, där ett kvalitetsmått och en inkomstkälla är antalet studenter som det individuella lärosätet och dess institutioner lyckas värva till sina utbildningar (Haikola, 20I5; Oldberg, 20I4). Inför varje läsår ges varje institution i uppdrag av sin fakultet att fylla ett visst antal studieplatser, och institutionen tilldelas ett förskott motsvarande detta antal. Studieplatserna beräknas dels i antalet registrerade studenter per läsår (helårsstudenter/hst, motsvarande en student som är inskriven för heltidsstudier om $60 \mathrm{hp}$ ), dels i antalet examinerade studenter per läsår (helårsprestationerl $h p r$, motsvarande en student som uppnår godkända resultat för heltidsstudier om $60 \mathrm{hp}$ ). ${ }^{\mathrm{I}}$ För 2018 beräknade Historisk-filosofiska fakulteten vid Uppsala universitet att Institutionen för kulturantropologi och etnologi skulle ha 268 helårsstudenter och en genomströmning på 68 \% (således ett utbildningsuppdrag på 268 hst och 182 hpr). När uppföljningen görs efter läsårets avslut blir institutionen återbetalningsskyldig om den inte uppfyllt sitt uppdrag, och riskerar att få ett mindre uppdrag (med mindre medel) nästkommande år. Eftersom ersättningen är högre per registrerad student (hst) än per examinerad student (hpr), blir summan mindre att betala tillbaka om institutionen underpresterar i form av genomströmning snarare än antalet registrerade studenter. Institutionen får ersättning (hst) även för antagna studenter som aldrig deltagit i undervisningen, såvida inte dessa studenter aktivt avregistrerar sig senast tre veckor efter kursstart. Mellan 2OII och 2013 höjdes ersättningsbeloppet per helårsstudent till humanistisk, teologisk, juridisk och samhällsvetenskaplig utbildning med $30 \%$, medan ersättningsbeloppet per helårsprestation inte höjdes alls. Relationen mellan ersättningen för antalet registrerade och antalet godkända studenter kom därmed att ändras till fördel för det förstnämnda måttet. Dessa faktorer utgör således incitament hos högskoleinstitutioner, inte 
minst inom humanistisk, teologisk, juridisk och samhällsvetenskaplig utbildning, att investera mer i att värva studenter till sina program och kurser än i att säkerställa att registrerade studenter fullföljer utbildningen.

Studieavhoppen hos resterande fjärdedel av informanterna i vår studie, däremot, hade i stor utsträckning att göra med studieovana, läs- och skrivsvårigheter och neuropsykiatriska utmaningar. Vår studie indikerar att flertalet av dessa studenter inte får sina behov av, och rättigheter till, särskilt stöd tillgodosedda. Anledningen är att studenterna i fråga inte känner till, orkar eller vågar ta kontakt med de stödmekanismer som finns. Detta pekar på en viktig psykosocial faktor. Studenter med funktionsvariationer som försvårar studier drabbas lätt av känslor av skam, underlägsenhet och oro för misslyckande. De bekräftar en avhoppsproblematik som tidigare uppmärksammats i pedagogisk forskning, nämligen ett samband mellan studenters underprestation, skamkänslor och studieavhopp (Turner et al., 2002. Se även Castellanos \& Jones, 2003:IIIff; Peelo \& Wareham, 2002:I39ff; Quinn, 2005). Vår studie illustrerar hur studenters skamkänslor förstärks av deras upplevda frånvaro av nära kontakt med, och stöd från, institutionen och andra studenter. Denna fråga är inte minst viktig för humanistisk och samhällsvetenskaplig utbildning. Idag läser allt fler studenter med funktionsvariationer, såsom dyslexi och läs- och skrivsvårigheter, på högskolan. Många av dessa har fått kämpa hårt genom grund- och gymnasieskola och tagit examen med låga betyg (Ingesson, 2007; Milrad, 20Io). Humanistiska och samhällsvetenskapliga ämnen innehåller många utbildningar med relativt låga antagningspoäng. Därför är det inte orealistiskt att anta att de även har ett relativt stort antal studenter med särskilda, pedagogiska behov. Samtidigt har dessa ämnen begränsade undervisningsresurser (TCO, 2013). Detta innebär en utmaning för berörda institutioner att bemöta dessa studenters upplevda brist på social samhörighet och kontakt med personal och övriga studenter.

De två olika avhoppstyperna illustrerade i denna artikel skildrar hur studieavhopp, för den enskilda individen, kan förknippas med både hoppfullhet och hopplöshet. De som väljer att hoppa av har större möjlighet att lämna studierna på ett strategiskt sätt, som exempelvis gör att de kan tillgodoräkna sig vissa högskolepoäng $\mathrm{i}$ andra, framtida studier. I vår studie såg de frivilliga avhopparna sina avhopp som en språngbräda till andra studier och de uttryckte en stark tilltro till möjligheterna att uppnå en högskoleexamen. De som hade hoppat av sina studier ofrivilligt, däremot, såg studieavhoppet som ett misslyckande och något som närde en rädsla för att aldrig uppnå en högskoleexamen. Dessa indikerar att studieavhopp som sker ofrivilligt lämnar lite utrymme åt studenten till strategiska val och riskerar att utmynna i en högskoleerfarenhet präglad av studieskulder, socialt utanförskap och försämrat självförtroende.

Vidare pekar båda avhoppstyper på hur genomströmningsproblematiken är ett samspel mellan individuella och strukturella faktorer - på institutions-, universitets- och nationell nivå. Tidigare skrev vi att studieavhopp är ett wicked problem (Rittel \& Webber, 1973). Det vill säga orsakerna är många och ofta sammanlänkade på komplexa och skiftande sätt, vilka gör dem svåra att effektivt motverka genom enstaka, avgränsade strategier (Beer \& Lawson, 20I7). Detta innebär dock inte att de inte kan motverkas alls. Beer och Lawson (2017) menar att nyckeln ligger i större, kollaborativa insatser där avhoppsproblematiken och dess lösningar utforskas av ett nätverk av olika aktörer som möjliggör mer omfattande angreppssätt. Avhoppsproblematiken bör vidare adresseras utifrån en lärandeansats där kunskapsmålet inte är att finna tydlig kausalitet utan snarare att förstå dynamiken i föränderliga förhållanden mellan olika faktorer, aktörer och system. Vi menar på liknande sätt att genomströmningsproblematiken kräver en mer omfattande studie av de föresatser med vilka studenter söker sig till och lämnar kurser och program. Vår studie pekar exempelvis på behovet av lands- och lärosätesövergripande analyser av 


\section{Molly Sundberg och Paul Agnidakis}

studenters fulla studiebana. Detta eftersom många studenter som hoppar av en enskild kurs eller ett program inte lämnar högre utbildning som sådan utan endast den enskilda kursen/programmet, i utbyte mot studier vid andra institutioner eller lärosäten. I studentens hela studiehistoria kan mönster urskiljas som till exempel fångar upp studenter med särskilda utmaningar liksom studenters strategier för att uppnå önskad examen. Vår studie indikerar även värdet av kvalitativ, djuplodande forskning om studieavhopp som komplement till större, enkätbaserade studier och statistiska undersökningar av studieresultat och kursregistreringar. Endast genom ingående och relativt förutsättningslösa samtal med enskilda studenter har denna studie gett insikt i vikten av studenters generella syn på högre studier och relationen till utbildningsansvariga för problematiken kring avhopp från den enskilda kursen eller programmet.

\section{FÖRFATTARPRESENTATION}

Molly Sundberg är disputerad forskare och lärare i antropologi vid Institutionen för kulturantropologi och etnologi vid Uppsala universitet. Hennes forskning fokuserar på internationellt utvecklingssamarbete i Tanzania samt medborgarskapsutbildning och statlig styrning i Rwanda. Hennes undervisning berör antropologisk metod, konfliktstudier, Afrikastudier samt utvecklingsantropologi.

Paul Agnidakis är disputerad forskare och lärare i etnologi vid Institutionen för kulturantropologi och etnologi samt Institutionen för arkiv, bibliotek och museer (ABM) vid Uppsala universitet. Hans forskning fokuserar på komplexa, rumsliga representationer som omfattar landsbygd och stad, förfluten tid och nutid samt kulturarvsdimensioner. Utöver undervisning $i$ hans egna forskningsrelaterade ämnen undervisar han i etnologiska och ABM-relaterade perspektiv och metoder.

\section{NOTER}

I Organisationen för ekonomiskt samarbete och utveckling.

2 Siffran $86 \%$ avser generella program. Prestationsnivån för yrkesprogram ligger på ca $90 \%$ (UKÄ, 2017b:45).

3 Se exv. hemsidan www.Antagningspoäng.se

4 Lärosätenas medverkan har bestå̆tt i att kartlägga befintlig praxis för "hur institutioner och förvaltning följer upp och stödjer studenter och alumner i ett kvalitetsfrämjande syfte" (Smidt, odaterad:3). Resultaten har hittills berört själva systemen för att mäta studentgenomströmning, snarare än genomströmningsproblematiken i sig (se exv. Smidt, 2013).

5 Uppsala universitets version av LADOK, ett nationellt IT-system för dokumentation av studenters registrering och resultat vid högre lärosäten i Sverige.

6 Generellt ledningsinformationssystem, innehåller data om universitetets ekonomi, studenter m.m.

7 Däremot hade ett fåtal av våra informanter deltagit i kurser för vilka någon av oss artikelförfattare/lärare senare tagit över ansvaret. I och med att kursernas utformning och innehåll i stor utsträckning bestäms av kursansvarig lärare, är vårt intryck att detta inte hindrade studenterna från att framföra eventuell kritik av kurser som sett betydligt annorlunda ut när någon annan än vi ansvarat för dem.

8 Denna artikel baseras delvis på ett projekt finansierat av Rådet för lika villkor vid Uppsala universitet. Projektet syftade till att undersöka hur ojämlika villkor kan ligga till grund för studieavhopp. Den här typen av projekt prövas i regel inte i Etikprövningsnämnden, varför inte heller denna studie har gjort det.

9 Exempelvis på grund av allt för bullrig omgivande miljö eller när intervjun genomfördes via telefon.

Io Att detta motsäger tidigare forskning kan möjligtvis bero på studiens begränsade antal distansstudenter.

II Här avses framförallt ADHD, Aspergers syndrom, autism och Tourettes syndrom.

I2 Detta reflekterar en trend inom högre utbildning: Antalet studenter som studerar yrkesexamensprogram (vilket länge har varit större än antalet som studerar på generella program eller fristående kurser) har ökat de senaste IO åren. Sedan 2012/13 studerar fler personer på generella program än fristående kurser i Sverige (UKÄ, 2017b:37).

I3 Detta inbegriper dock inte exv. Sveriges I55 folkhögskolor och 40 yrkeshögskolor.

I4 För en inskriven heltidsstuderande som presterar 60 högskolepoäng erhåller högskolan således I,o hstersättning + I,o hpr-ersättning. 


\section{KÄLL- OCH LITTERATURFÖRTECKNING}

Agnidakis, P. (2013). Rätten till platsen. Tillhörighet och samhörighet i två lokala industrisamhällen under omvandling. Doktorsavhandling. Höör: Brutus Östlings Bokförlag Symposion.

Agnidakis, P. (2018). Ethnology: Theories and methods. I: H. Callan (Red.). Wiley-Blackwells International Encyclopedia of Anthropology. Chichester: Wiley-Blackwell.

Allen, W. R., Teranishi, R.T., Bonous-Hammarth, M. (Red.). (2012). As the world turns: implications of global shifts in higher education for theory, research and practice. Bingley: Emerald.

Andersson, S., Andersson Chronholm, J., \& Gelin, B. (2012). Avhopp och genomströmning: Hur ser det ut och vad kan man göra? I: G. Gunnlaugsson (Red.). Universitetspedagogisk utveckling och kvalitet - i praktiken! Uppsala: Uppsala universitet, Avdelningen för universitetspedagogisk utveckling.

Arvidsson, A. (1998). Livet som berättelse. Studier i levnadshistoriska intervjuer. Lund: Studentlitteratur.

Barefoot, B. O. (2004). Higher education's revolving door: confronting the problem of student drop out in US colleges and universities. Open Learning: The Journal of Open, Distance and e-Learning 19(1): 9-18.

Beer, C., \& Lawson, C. (2017). The problem of student attrition in higher education: An alternative perspective. Journal of Further and Higher Education 41(6):773-784.

Borman, K. M., Halperin, R. H., \& Tyson, W. (2010). Becoming an Engineer in Public Universities Pathways for Women and Minorities. New York: Palgrave MacMillan.

Castellanos, J. \& Jones, L. (Red.). (2003). The majority in the minority. Expanding the representation of Latinalo Faculty, Administrators and Students in Higher Education. Sterling, Virginia: Stylus Publishing.

Centrala Studiestödsnämnden (CSN). (2018). Studieresultat. Hämtad den 15 mars 2018 från https:// www.csn.se/bidrag-ochan/studiestod/studiemedel/studieresultat.html\#expand:svid10_3bc72e5c15 cce36b423ec0d

Craith, M. N., Kockel, U., \& Johler, R. (Red.). (2008). Everyday Culture in Europe. Approaches and Methodologies. Farnham: Ashgate.

Ehn, B., Löfgren, O., \& Wilk, R. (2016). Exploring Everyday Life. Strategies for Ethnography and Cultural Analysis. London: Rowman \& Littlefield.

Englund, Tomas (2004). Nya tendenser inom pedagogdisciplinen under de tre senaste decennierna. Pedagogisk forskning i Sverige 19(1):37-49.

Flemming, J. (2012). Enhancing Minority Student Retention and Academic Performance. What We Can Learn from Program Evaluations. San Fransisco: Jossay Bass.

Frykman, J. (2012). A Tale of Two Disciplines: European Ethnology and the Anthropology of Europe. I: U., Kockel, M. N., Craith \& J. Frykman (Red.). A Companion to the Anthropology of Europe. Chichester: Wiley Blackwell.

Haikola, L. (2015). Högre utbildning under tjugo år. Betänkande av Utredningen om högskolans utbildningsutbud. I: SOU 2015:70. Stockholm: Elanders Sverige.

Hede, G., \& Wikander, L. (1990). Avbrott och studieförseningar på juristutbildningen: en uppföljning av antagningsomgaingen ht 1983 vid Uppsala universitet. Uppsala: Uppsala universitet, Pedagogiskt utvecklingsarbete.

Hu, S., \& Li, S. (Red.). (2011). Using typological approaches to understand college students experiences and outcomes. Hoboken, NJ: Wiley Periodicals.

Huang, G., Taddese, N., \& Walter, E. (2000). Entry and Persistence of Women and Minorities in College Science and Engineering Education. Washington: U.S. Department of Education. Office of Educational Research and Improvement.

Högskolelagen (1992:1434) 1 kap. 5 \$ högskolelagen.

Ingesson, G. D. 2007. Growing Up with Dyslexia: Interviews with Teenagers and Young Adults. School Psychology International 28(5):574-591.

Jönsson, U., \& Johansson, B-M. (2007). Varför Hoppar visa studenter av sin högskoleutbildning? En studie om orsaker till avhopp från studie- och yrkesvägledarprogrammet vid Malmö Högskola. Malmö: Malmö högskola, Lärarutbildningen Individ och Samhälle.

Loresco, R. (2013). An Examination of student Stop-Outs and Stay-Outs in a Community College: A Qualitative Investigation. Minneapolis: Capella University Press. 


\section{Molly Sundberg och Paul Agnidakis}

Lutta, J. (2011). Student retention and dropout in higher education systems. Saarbrücken: LAP.

McGivney, V. (2003). Leaving the course. Non-completion and retention mature students in further and higher education. Liecester: NIACE.

Milrad, M. B. (2010). Studenter med läs- och skrivsvårigheter som deltagare i högre utbildning. Doktorsavhandling. Växjö: Linnéuniversitet, Institutionen för pedagogik, psykologi och idrottsvetenskap.

Organisation for Economic Cooperation and Development (OECD) (2013). Education at a Glance (2013): OECD Indicators. Paris: Organisation for Economic Cooperation and Development.

Oldberg, E. (2014). Privata donationer allt viktigare. SVT Nyheter. Hämtad den 15 mars 2018 från https:// www.svt.se/nyheter/lokalt/vast/privata-donatinoer-allt-viktigare

Peelo, M., \& Wareham, T. (2002). Failing students in higher education. Buckingham: Open University Press.

Quinn, J. (Red.) (2005). From life crisis to lifelong learning. Rethinking working-class 'dropout' from bigher education. York: Joseph Rowntree Foundation.

Rittel, H. W. J. \& M. M. Webber. (1973) Dilemmas in a General Theory of Planning. Policy Sciences 4:155-16.

Saunders, A. G. (2010). Neoliberal ideology and public higher education in the United States. Journal for Critical Education Policy Studies 8(1):41-77.

Scheg, A. G., \& Shaw, M. (2018). Fostering Effective Student Communication in Online Graduate Courses. Hershey PA: IGI Global.

Simpson, O. (2003). Student retention in online, open and distance learning. London: Kogan Page.

Smidt, H. (odaterad). Trackit - att följa och följa upp studentens "studieupplevelse." Hämtad 1 oktober 2018 från https://www.uhr.se/lika-mojligheter/trackit---studentuppfoljning-for-battre-stod/

Smidt, H. (2013). Trackit Uppsala universitet: En kartläggning av hur Uppsala universitet följer och följer upp sina studenter före, under och efter studierna. Uppsala: Uppsala universitet.

Svensson, A. (2004). Gymnasiebetyg eller högskoleprov som urvalsinstrument? Fallet civilingenjörsutbidningarna. Pedagogisk forskning i Sverige 9(1): 15-36.

Sveriges statistiska centralbyrå (SCB). (2018). Arbetslösheten tog fart under finanskrisen. Hämtad 15 mars 2018 från http://www.scb.se/hitta-statistik/sverige-i-siffror/samhallets-ekonomi/arbetslosheten/.

Tinto, V. (1987). Leaving college. Rethinking the Causes and Cures of Student Attrition. Chicago: The University of Chicago Press.

Tjänstemännens centralorganisation (TCO). (2013). TCO granskar: Lärarledd tid och kvalitet i den högre utbildningen \#7/13. Hämtad den 15 mars 2018 från German Bender. https://www.tco.se/globalassets/0713-lararledd-tid_1-1_w.pdf

Turner, J. E., Husman, J., \& Schallert, D. L. (2002). The importance of students'-goals in their emotional experience of academic failure: Investigating the precursors and consequences of shame. Educational Psychologist 37: 79-89.

Universitetskanslersämbetet. (2013). Arsrapport 2013 for universitet och högskolor. Stockholm: UKÄ.

Universitetskanslersämbetet. (2017a). Tidiga avhopp frän högskolan. Analyser av genomströmning på de tio största yrkesexamensprogrammen. Rapport 2017:17. Författad av Fredrik Svensson och Sofia Berlin Kolm. Stockholm: UKÄ.

Universitetskanslersämbetet. (2017b). Airsrapport 2017 för universitet och högskolor. Stockholm: UKÄ.

Universitets- och högskolerådet. (2017). Utbildning går i arv. Inställning till högre utbildning bland svenska folket. Stockholm: UHR.

Universitets- och högskolerådet. (2018). Examina på universitet och högskola. Hämtad den 15 mars 2018 från https://www.uhr.se/studier-och-antagning/tilltrade-till-hogskolan/Examina-pa-universitet-och-hogskola/

Uppsala universitet. (2017). Mångfaldsrapport 2016: Rapport om födelsebakgrund hos anställda, studenter och doktorander vid Uppsala universitet. Uppsala: Uppsala universitet, Personalavdelningen. 